\title{
THE ACADEMIC COMMUNITY PERCEPTION ABOUT IMPLEMENTATION OF UI GREENMETRIC-WASTE MANAGEMENT CRITERIA AT PRESIDENT UNIVERSITY
}

\author{
Kezia Kusumaningtyas ${ }^{1}$, Ramadhani Fithratullah ${ }^{2}$ and Clara Meluk ${ }^{3}$ \\ Environmental Engineering, President University \\ Jababeka Education Park Jalan Ki Hajar Dewantara, Kota Jababeka, RT.2/RW.4, \\ Mekarmukti, Cikarang Utara, Bekasi, Jawa Barat 17550 \\ ${ }^{1}$ ningtyasecha@gmail.com, ${ }^{2}$ Ramadhani.fithratullah@yahoo.com , ${ }^{3}$ clarameluk1996@gmail.com
}

\begin{abstract}
Universitas Indonesia is the initiator of a UI GreenMetric World University international ranking system, which is a ranking system that aims to bring together universities that share the same goals in terms of sustainability. At present President University has participated in the ranking system. To find out the perceptions of the academic community on the implementation of the ranking system at President University, one of the criteria that is examined is waste management as one of the parameters of the GreenMetric UI. To get data, the method of direct observation is done to get the desired data by making a questionnaire in the form of a google form filled in by students and interview staff and operators at President University. Based on the results of data processing, it can be seen that the academic community at President University campus in general does not fully understand the waste management system on campus. So that education needs to be done about the management system developed on the internal campus of President University.
\end{abstract}

Keywords: President University, UI GreenMetric World University Ranking, waste management

\begin{abstract}
Abstrak: Universitas Indonesia menjadi penggagas suatu sistem rangking internasional UI GreenMetric World University Ranking, yang merupakan suatu sistem rangking yang bertujuan untuk menyatukan universitas yang memiliki tujuan yang sama dalam hal keberlanjutan. Saat ini President University telah turut berpartisipasi dengan sistem rangking tersebut, untuk mengetahui persepsi komunitas akademik terhadap impelementasi sistem rangking di President University, salah satu kriteria yang coba dikaji adalah mengenai pengelolaan sampah sebagai salah satu parameter dari UI GreenMetric. Untuk mendapatkan data, metode pengamatan langsung dilakukan untuk mendapatkan data yang diinginkan dengan cara membuat kuesioner dalam bentuk formulir google yang diisi oleh mahasiswa dan staf wawancara dan operator di President University. Berdasarkan hasil pengolahan data, dapat diketahui bahwa komunitas akademik di kampus President University secara umum belum begitu memahami sistem pengelolaan sampah di internal kampus. Sehingga perlu dilakukan edukasi mengenai sistem pengelolaan sampaah yang dikembangkan di internal kampus President University.
\end{abstract}

Kata Kunci: President University, UI Peringkat GreenMetric World University, pengelolaan limbah

\section{INTRODUCTION}

Nowadays global warming and climate change is main topic in this era because of the temperature of earth is increasing. Several century temperature of earth was increase $0.7 \pm 0.8^{\circ} \mathrm{C}$. This phenomenon may happen because of several compound that produce from human activities, they are $\mathrm{CO}_{2}, \mathrm{CFC}, \mathrm{CH}_{4}, \mathrm{HF}, \mathrm{SO}_{x}, \mathrm{NO}_{x}$, etc. Emission was produce from fuel and combustion of forest/ or other kind of combustion. Emission simply said greenhouse gases (GHGs), the most of causing global warming and climate change (Kulkarni, 2017). People nowadays looking the solution for this problem, the solution obviously decrease producing of emission (Puspadi et al, 2016). Sustainability movement is nowadays event to sign that people aware to the environment.

The sustainability movement in higher education has been existed since the 1990s has made significant progress in research are, campus operations, strategic planning, and community service. Campus demonstrates its concern for ecological environment, by carrying out a series of new activities in sustainability. Sustainability campus is a global awareness, that every activity that is implemented by the campus and operational has an impact on the environment. There are 2 ways to support 
campus sustainability, greening the campus and educating the academic community (Simangunsong, 2017). Greening the campus is instilling behavior of environmental friendly to all dimensions campus of infrastructure and operations. Educating the academic community that every activity has a good impact and bad impact can change the environmental. A collection of usual activities will become a habit. To prevent another impact have change the environmental there are several efforts sustainability which broadly defined to change in campus such as in operations, administrative planning, academic curriculum and facilitating research positive environmental change (Ravesteyn, 2014).

Green campus have several principles such as protecting the environment, lowering operating costs, improving the health and quality of the learning environmental, and integrating learning opportunities with the built environment. It's an ideal of green campus must be in standards. In the other hand green campus in an effort of sustainability campus means there are energy efficiency, can reduction in operational cost and reduction of environment (Kulkarni, 2017).

To achieve the goals many of campus has made the standard of green campus following the principles. UI GreenMetric World University Rankings is an initiative of Universitas Indonesia which being launched in 2010, and 619 universities with 77 countries in the world has participated in this organization. As the aim of this ranking to provide the result online survey regarding the current conditions and policies related to Green Campus and Sustainability in the universities all over the world. UI GreenMetric has standard or criteria regarding the ranking such as setting and infrastructure, energy and climate change, waste, water, transportation and education.
President University as the participant of UI GreenMetric World University Ranking has shown the awareness to the environment. But to be the participants it does not mean President University is a green campus, President University should completed all the criteria of UI GreenMetric. From six criteria we will take one criteria to be considered which waste criteria to be our focus research.

If there was a waste it must be a technique to be the solution. Solid Waste management is the technique to manage the waste and it is the multi nations problem that proved by perspective of history and perspective of UN policy, existent problem of Municipal Solid Waste Management in Kenya that amount of waste produced by their own citizen is growing alongside the uncontrolled disposal. All of this similar case needed to be seen as un-sustainability-lifestyle that needed to be fixed and start from the higher education to be the pioneers.

The aim of this paper is to find out President University civitas's perception and understanding about implementation of UI GreenMetric standard in President University, especially about the waste management.

\section{MATERIAL AND METHODS}

In order to get the data, we used two methods. The first method focused on collecting document from students in three batch (2016, 2017 and 2018). Filling out questionnaires use google form consist of 7 numbers of questionnaires and 31 respondents to see perspective of students about the process of waste in President University. Participant comes from three batches, to control the result. For second method, authors used interview methods, took 4 interviewed consist of 3 cleaning service and 1 staff campus. The objects are staff in university and representative of operators who responsible in waste management in university. 
1. Questionnaires in the form of google forms: the information from student based on how far they know their campus. But because of authors make a control data by did survey to three batch. Estimation of the result is in actual and controlled.

2. Interview session : President University have department called General Affair (GA) where every student have a business with campus as general can go to that department. To get the data, authors interviewed staff on General Affair. In addition to complete the data, some operators who responsible to collect the waste also interviewed.

The aim of this method is to be able to collect data in detail, depth and also actual.

\section{RESULT AND DISCUSSION}

In every program, activity, or event also produce a waste but it could be maintained base on those who concerned to the program, activity, or event. From 31 responses (from batch active; 2016, 2017, 2018) they said, 29\% not applicable, $22.6 \%$ partial (1\% - $25 \%$ of waste), $32.3 \%$ partial ( $>25 \%-50 \%$ of waste) and partial $(>50 \%-75 \%$ of waste) the value are $16.1 \%$ for each.

Waste criteria standard according to UI GreenMetric is a treatment of waste and any recycling activities are major factors in creating a sustainable environment.

\section{Recycling program for University waste}

\section{1 responses}
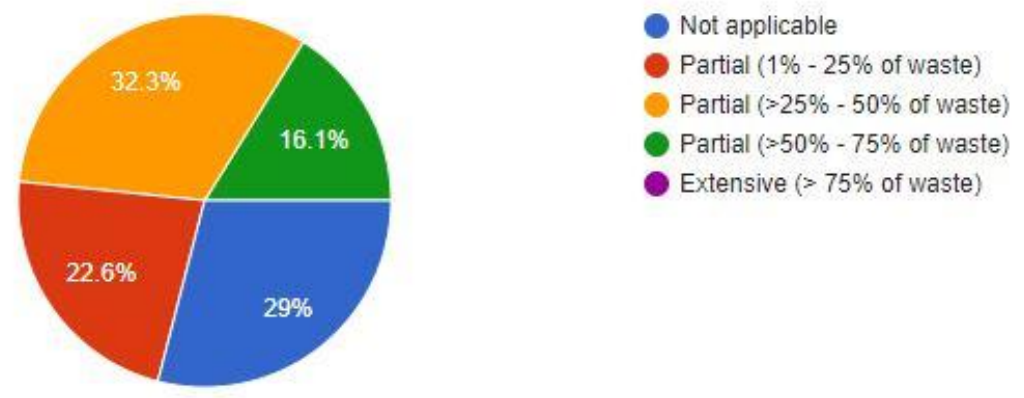

Figure 1. Recycle program for University waste

After we did 2 methods, first took a data using form and filled by 15 respondents from 3 batches, and second took a secondary data from interviewing the staff and operators. So, here are the results shown as below.

\section{Data Analysis}

Following the result of the form, there are six figures according to the indicators point of waste of UI GreenMetric, are shown the opinion from students from three batch:

1. Recycle Program for University Waste

2. Program to Reduce the Use of Paper and Plastic in Campus

3. Organic Waste Treatment

4. Inorganic Waste Treatment

5. Toxic Waste Treatment

6. Sewerage Disposal 
The second UI GreenMetric give another point which a program to reduce the use of paper and plastic in campus, according to opinion from student most said is not applicable with the amount $25.8 \%$

\title{
Program to reduce the use of paper and plastic in campus
}

31 responses

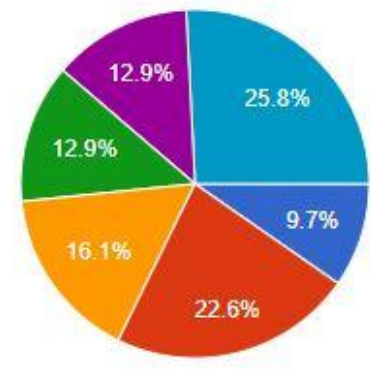

\author{
Not applicable \\ 1 program \\ 2 programs \\ 3 programs \\ More than 3 programs \\ NOt applicable
}

Figure 2. Program to reduce the use of paper and plastic in campus

and the rest said there still some programs exist to reduce the use of paper and plastic in campus.

Mostly organic waste consists of food which came from student and staff of campus. The responded said $32.3 \%$ no treatment for organic waste or the waste just thrown up to the place, simply said open dumping. $12.9 \%$ extensive.

\section{Organic waste treatment}
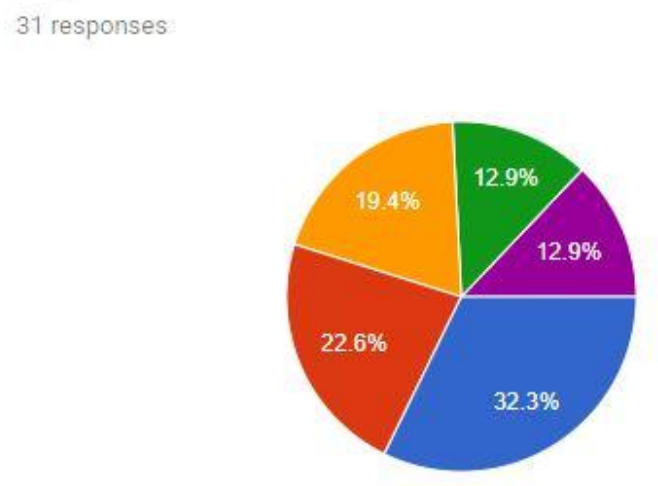

Open Dumping

Partial ( $1 \%-25 \%$ treated)

Partial $(>25 \%-50 \%$ treated)

Partial $(>50 \%-75 \%$ treated)

Extensive ( $>75 \%$ treated and

recycled)

Figure 3. Organic waste treatment

Inorganic waste mostly consists of plastic and polythene, commonly people consume. Have a same result with organic waste, $29 \%$ respondents said no treatment, the operator just burned it in open condition. There same number between partial $(1 \%-25 \%$ treated) and extensive $(>75 \%$ treated and recycled, the number $20 \%$ for each. 


\section{Inorganic waste treatment}

31 responses

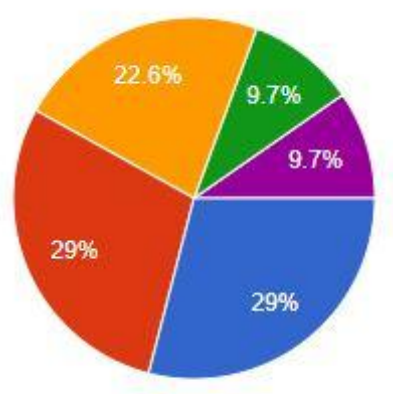

Burned in open

Partial ( $1 \%-25 \%$ treated)

Partial $(\geqslant 25 \%-50 \%$ treated)

Partial $(>50 \%-75 \%$ treated)

- Extensive $>75 \%$ treated and recycled)

Figure 4. Inorganic waste treatment

Toxic waste consists of several chemical that have potential effect to human health. But it is a pity that $42.5 \%$ of respondents said, there's no management treatment to toxic waste.

Based on the knowledge about the campus, $38.7 \%$ agreed that sewerage

\section{Toxic waste treatment}

31 responses disposal is treated technically, but close to previous $35.5 \%$ agreed sewerage disposal is untreated into waterways. The rest agree the sewerage is treated conventionally and just a pieces respondent said the sewerage is treated for cycling.

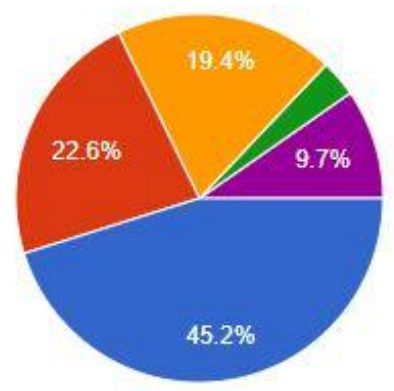

Not managed

Partial ( $1 \%-25 \%$ treated)

Partial $(>25 \%-50 \%$ treated)

Partial ( $>50 \%-75 \%$ treated)

Extensive ( $>75 \%$ treated and recycled)

Figure 5. Toxic waste treatment

Another collection data we did interview to the operators and staff that responsible to the waste. According the result from interview, President University just disposed the waste without any treatment, said the operator. The parties from
President University do not know where their waste ends, which they know only collects waste and will be given to vendors, Sir Iwan Bin Aca as the vendors. 


\section{Sewerage disposal}

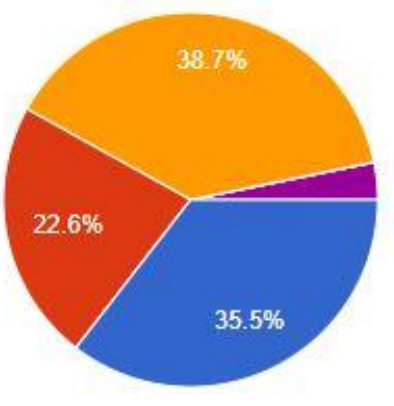

Untreated into waterways

Treated conventionally

Treated technically

Treatment for down cycling

Treatment for up cycling

Figure 6. Sewerage disposal

We calculated in one day the average waste for Building $\mathrm{B}$ only produce 8 big polybag with the collecting time $1.30 \mathrm{pm}$ and $9.30 \mathrm{pm}$. The vendor will took the waste 3 times in a week (Monday,
Wednesday and Friday) with the cost $2,632,000,00-$ Rupiah in a month. The table 1 shown consideration for the cost of disposal waste.

Table 1. The cost of waste disposal

\begin{tabular}{ccc}
\hline Cost in one times pickup & Pickup quantity in a month & Cost in a month \\
\hline $\operatorname{Rp} 2,632,000$ & 1 time & $\operatorname{Rp~2,632,000~}$ \\
& Total in a year & $\mathbf{R p ~ 3 1 , 5 8 4 , 0 0 0}$ \\
\hline
\end{tabular}

\section{Discussion}

Waste criteria standard according to UI GreenMetric have six indicators, as the point of the form. University sued to concern in waste treatment, but we see from the result in average number close to a half percent the waste in President University untreated, or we said unproperly treatment.

Actually data we use is an assumption from students where is based on the knowledge of each student. In solution President University needs to increase the awareness of academic community about their waste and improve the technology in waste treatment in order to meet the indicators issued by UI GreenMetric ranking. To meet the criteria and indicators of waste, university should make a recycling program, following principle green movement 3R (Reduce, Recycle and
Reuse). Start to use sustain material then, university waste could be more effective and efficient. To strengthen its foundation, university can establish regulation regarding sustainability campus material, so that can implement $3 \mathrm{R}$. The regulation must be followed for all academic community.

The lack infrastructural facilities and limited resources have caused waste not to effectively serve the universities for the treatment and disposal of solid waste, and most of academic community proper chose waste disposal treatment. By this problem must be start from university to give education to the community so can shared the awareness in campus environment. From the experience President University has many of events, even it's a major event, campus event, or community event, not often they consumed single used 
property for decoration. Food also consideration in this problem, because most event they consumed drinking water glass and the packaging of the food consumed plastic.

In order to meet criteria and indicators several methods could be the program in university, waste reduction at source level and scientific methods of SWM. There are scientific methods of SWM (Solid Waste Management) waste stream segregation, composting and biogas extraction of organic wastes, recycle of paper, plastic and metal wastes, and incinerator of hazardous waste (Rajamanikam, 2014).

\section{Waste stream segregation}

Honestly before the latest canteen there was waste segregation. University provides three characteristic of waste, and then customer should put the waste compatible to the bin. But for the latest canteen there is no waste segregation. Besides the infrastructure for the waste, habit of community contribute big influence. Even the university gave the facilities but the community has not awareness, it's useless. Education is still number one to improve the environment of university. Together should change the perception of community to participate in waste segregation movement.

\section{Composting and biogas extraction of organic waste}

Following the result, $40 \%$ of student said the organic waste untreated and dispose in open dumping. As we know open dumping may cause potential health impact to human life. The solution we can do composting and biogas extraction.

UGM has implemented 2 type of technology such as compost or indore heap, and windrow composting using indore heap take method takes 60 days, for windrow composting takes 45 days process. Nevertheless windrow composting takes a shorter processing time, but has its deficiencies. Compared with indore heap, windrow method have not a leachate water treatment during the composting process. So, it is make leachate have to back to the heap with leachate flow into the container so the nutrients that contained in leachate water isn't wasted.

Vermicompost is an alternative method, a product of composting process using various species of worms, to create a mixture of decomposing vegetable or food waste. This method has shorter processing time rather than windrow composting, that is 30 days. Vermicompost method will produce compost can be used for plant fertilizer (Setyowati, 2018).

\section{Recycle of paper, plastic, and metal wastes}

Recycling is clearly a waste-management strategy, but it can also be implemented in industrial ecology, where the concept of industry is in natural ecosystem and no waste come up from product.

Easy step for recycle waste from reuse as long as the goods in good condition and try to use it. But it cannot be easy if the individual lacks awareness and care. In order to engage and to enhance academic community recycling behavior used an effective tool like share the information of recycling in terms of feedback, publicity, promotion, or a well-designed communication so the community interest to participate in recycle movement (Zhu, 2016).

\section{Incineration of hazardous waste}

Basically hazardous waste is very dangerous for human health. It make hazardous waste must be treatment properly, or it will give nor chronic or acute impact to human health.

During incineration of hazardous waste produce another waste like fly ash and bottom ash. There was a study about reused from fly ash and bottom ash to be secondary building material. Its mixture using Municipal Solid Waste Incineration (MSWI) bottom ash (BA) and air pollution control fly ash (Valle-Zermeno et al,). 
Researcher from Spain has proved that from mixturing MSWI bottom ash with air pollution control fly ash can be secondary building material which also considered for the cost, this a sustainability program.

\section{CONCLUSION}

In Order to build a sustain environment regarding global warming that has given an impact, climate change. Green campus is an effort for sustain in campus environment, several university in Indonesia has a green campus based on their criteria but with several classification principal of green campus need to be fulfilled. Universitas Indonesia is a university that initiative to make an international green campus organization is UI GreenMetric World Ranking University. President University is participant of the organization regarding to green campus, which mean President University must follow the standard of UI GreenMetric in six indicators. Waste as the criteria on this journal have six indicator. The result shown that President University is in the level still learning as participant of UI GreenMetric regarding the standard. President University needs to increase the awareness of academic community improve the technology of waste management to fulfill the standard of waste criteria, like more campaign about waste management, impact of high consume can increase waste. Other solution is technology of waste treatment, the technical of treatment should to be improved. Not only following the standard of UI GreenMetric but also for the health of environment.

\section{ACKNOWLEDGEMENT}

Thank you to the Almighty God in His guidance and wisdom because of the completion of this journal. We are also grateful to Miss. Ir. Temmy Wikaningrum, M.B.A, M.Si as the head of the Environmental Engineering study program who has guided us while working on the journal. And a lot of our gratitude goes to
Mr. Rijal Hakiki, S.S.T., M.T. as a lecturer who has provided information about the material in the journal. Do not forget we also expressed our gratitude to the informants we were willing to interview. Last but not least thank you to all authors for this reference for all information.

\section{REFERENCE}

Ravesteyn, Pascal, Henk P, Joris M.. (2014). Smart Green Campus : How IT can Support Sustainability in Higher Education. Pascal Ravesteyn

Simangunsong, Tuani Lidiawati. (2017). Pengelolaan Sampah Kampus untuk Mewujudkan Kampus Berkelanjutan (Sustainability Campus). Article DOI: 10.21070/prozima.v1i1.707

Kulkarni, Ramesh. (2017). Awareness about green campus opportunities amongst the educational institutions of north Karnataka. International Journal of Commerce and Management Research Volume 3; Issue 3 Page No. 79-82

Pusdadi, Nenes Anggi, MIA W, M RANGGA S. (2016). Perbandingan Kendala dan Tantangan Penerapan Konsep Green Campus di Itenas dan Unpar. Jurnal Online Institut Teknologi Nasional Vol. 2 | No. 2

R. Rajanikam and G. Poyyamoli (2014), Towards Zero-Waste Campus: Compositional Analysis of Solid Waste at The Staff Quarters To Frame Inclusive Sustainable Campus Waste Management System, IJIRSET (An ISO 3297: 2007 Certified Organization) Vol. 3, Issue 4 page 11258

O. Adelene, Joanneke K (2016), The Importance of Specific Recycling Information in Designing a Waste Management Scheme, MDPI Volume 1, Issue 2

Valle-Zermeno, R. del, J. Formosa, J.M. Chimenos, M Martinez, A.I Fernandez, Aggregate Material Formulated with MSWI Bottom Ash and APC Fly Ash For Use as Secondary Building Material

UI GreenMetric World University Ranking. 2010; http://greenmetric.ui.ac.id

Setyowati, Mega, Arif Kusumawanto and Agus Prasetya. 2018. Study of Waste Management Towards Sustainable Green Campus in Universitas Gadjah Mada, IOP Conf. Series: Journal of Physics

Zhu, Ning. 2016. Impact of Communication Appeals on Recycling Behaviours Among Undergraduate Students, Purdue e-Pubs 
JENV, Vol. 4, No. 1, April 2019: 28-36

Arthawidya, Jalu, Endro Sutrisno, Sri Sumiyati. 2017. Analisis Komposisi Terbaik dari Variasi C/N Rasio Menggunakan Limbah Kulit Buah Pisang, Sayuran dan Kotoran Sapi dengan Parameter C-Organik, N-Total, Phospor, Kalium dan $\mathrm{C} / \mathrm{N}$ Rasio Menggunakan Metode Vermikomposing, Jurnal Teknik Lingkungan, Vol.6, No.3

Latimer, Geoff, 2015, The Health and Environmental Impact of Hazardous Wastes, Ascend Waste and Environment Pty Ltd

Yukalang, Nachalida, Beverly Clarke and Kirstin Ross, 2018, Solid Waste Management Solutions for a Rapidly Urbanizing Area in Thailand Recommendations Based on Stakeholder Input, MDPI International Journal of Environmental Research and Public Health

Riley, Keith and Professor William Powrie Freng, 2015, Recycling Household Waste, Royal Academy of Engineering 